\title{
Salicylate effects on a monolayer culture of gastric mucous cells from adult rats
}

\author{
S OTA, M RAZANDI, S SEKHON, W J KRAUSE, A TERANO, H HIRAISHI, \\ AND K J IVEY \\ From The Department of Medicine, Long Beach Veterans Administration Medical Center, Long Beach, \\ University of California, Irvine, CA, USA
}

SUMmARY Aspirin, acetyl salicylic acid, damages gastric mucosal cells. This effect is considered related to its inhibition of prostaglandin synthesis. On the other hand, sodium salicylate has been reported to be cytoprotective against drug damage to gastric mucosa in vivo. ${ }^{2}$ One reason for this difference is that salicylic acid, unlike acetyl salicylic acid does not inhibit prostaglandin synthesis by gastric mucosa in vivo. Previous studies on tissue culture cells from our laboratory have required gastric mucosa from fetal rats; this was time consuming and expensive. The purpose of this study was to develop a primary cell culture of adult rat fundic epithelial cells and to test the effect of sodium salicylate on: (1) prostaglandin (PGE $)$ production, (2) cell viability, (3) reducing cell damage by sodium taurocholate. Gastric epithelial cells were isolated from adult rat stomachs and cultured on collagen gel. Cells reached confluency on day 4 at which stage fibroblasts were rarely seen $(<1 \%)$. Autoradiographic study showed that cultured cells incorporated [3-H] thymidine into nuclei. In histochemical studies, $94 \%$ of the cells contained PAS positive granules (mucous cells). Mucous granules were observed in the cytoplasm of the majority of cells by electronmicroscopy. These cells synthesised prostaglandin $\mathrm{E}_{2}$ as determined by radioimmunoassay. Indomethacin $10^{-4} \mathrm{M}$ strongly suppressed $\mathrm{PGE}_{2}$ production after 30 minutes while $10^{-3}$ and $10^{-4} \mathrm{M}$ sodium salicylate had no effect. Pharmacologic concentrations of $10 \mathrm{mM}$ sodium salicylate had no effect on PGE 2 production at 30 minutes and only weakly inhibited production after one hour incubation. Sodium salicylate up to 30 $\mathrm{mM}$ had no effect on cell viability, a concentration of $50 \mathrm{mM}$ being necessary to produce significant cell damage. Sodium salicylate $10 \mathrm{mM}$ significantly protected cells against damage induced by 10 mM sodium taurocholate. We conclude: (i) adult rat gastric mucous epithelial cells can be successfully cultured in vitro; (ii) prostaglandin synthesis is inhibited by indomethacin but not by low doses of sodium salicylate; (iii) sodium salicylate does not damage gastric mucosal cells except at very high concentrations; (iv) sodium salicylate protects against damage to cells induced by sodium taurocholate.

Sodium ( $\mathrm{Na}$ ) salicylate has been reported to protect gastric mucosa against damage by aspirin, ethanol and concentrated hydrochloric acid in vivo. ${ }^{12}$ Stimulation of endogenous prostaglandin $I_{2}$-like activity was associated with this cytoprotection,' but blockage of prostaglandin synthesis did not prevent

Address for correspondence: Kevin J Ivey, MD, Gastroenterology Section, Veterans Administration Medical Center, 5901 East Seventh Street, Long Beach, CA 90822, USA.

Received for publication 21 June 1988. such protection making it unlikely that this was the mechanism of protection. ${ }^{2}$

Cell culture of gastric epithelial cells is a valuable model for the study of cell function without systemic factors. Successful culture of gastric epithelial cells $\mathrm{s}^{2-5}$ has been reported but in order to establish cell growth and to avoid contamination, fetal tissue has been used in most cases. Soll et al reported a monolayer preparation of adult canine fundic mucosa which was mainly composed of chief cells. ${ }^{6}$ In 
their preparation, cell division was not observed. Furthermore, in order to establish cell growth in theirs and other culture systems, addition of hormonal factors was required which in itself, may alter the functional status of cultured cells.

As the in vivo studies with Na salicylate were done in adult rats, ${ }^{12}$ cultured cells from adult rats may be expected to more accurately reflect functions of adult gastric cells. Accordingly, we modified our established techniques for culture of baby rat gastric cell culture ${ }^{7}$ in order to culture adult rat gastric cells.

The morphologic characteristics of these cells, their ability to divide and to synthesise prostaglandins and the effect of sodium salicylate and indomethacin on prostaglandin synthesis were studied. In addition, the effect of sodium salicylate on cell viability and its ability to exert a cytoprotective effect in vitro were studied.

\section{Methods}

MATERIA LS

Medium I: Coon's modified Ham's F-12 medium ${ }^{8}$ (F-12 medium, KC Biological Inc, Lenexa, KS) containing $0.15 \mathrm{~g} / \mathrm{dl}$ collagenase $(120 \mathrm{U} / \mathrm{mg}$, GIBCO, Grand Island, NY), $100 \mathrm{U} / \mathrm{ml}$ penicillin, $100 \mu \mathrm{g} / \mathrm{ml}$ streptomycin, $25 \mu \mathrm{g} / \mathrm{ml}$ fungizone (these antibiotics and antimycotic (AA) were obtained from Irvine Scientific Co, Santa Ana, CA). Medium II: F-12 medium supplemented with heat inactivated $\left(\right.$ at $56^{\circ} \mathrm{C}$ for 30 minutes) $10 \mathrm{~g} / \mathrm{dl}$ fetal bovine serum (Armour Pharmaceutical Co, Kankakee, IL), 15 mM Hepes buffer (Sigma Chemical Co, St Louis, MO), fibronectin $(10 \mu \mathrm{g} / \mathrm{ml}$; Sigma) and AA described above. Trypsin was purchased from Sigma. [3-H] thymidine ([3-H]Tdr, specific activity $20 \mathrm{Ci} / \mathrm{mmol}),(125-\mathrm{I})$ prostaglandin $\mathrm{E}_{2}\left(\mathrm{PGE}_{2}\right)$ and 6-Keto-PGF $\mathrm{PG}_{1 \mathrm{a}}(6 \mathrm{KF})$ radioimmunoassay (RIA) kits were purchased from New England Nuclear, Boston, MA. Nuclear Track Emulsion (NBT-2), D19 and Rapid Fix were obtained from Eastman-Kodak, Rochester, NY.

\section{CELL PREPARATION}

The stomachs from rats (Sprague-Dawley Albino, Simonsen Lab, Gilroy, CA) weighing 250-350 g were placed in Hank's balanced salt solution (HBSS). The stomachs were opened along the lesser curvature and the fundic area was excised. The fundic musoca was washed vigorously with three changes of HBSS. The mucosa was incubated in $20 \mathrm{ml}$ of medium I at $37^{\circ} \mathrm{C}$ in a shaking water bath for 60 minutes. The medium was discarded and mucosa incubated in $20 \mathrm{ml}$ fresh medium I for an additional 15 minutes. This medium was discarded and the mucosa was manually shaken for two minutes in $20 \mathrm{ml}$ fresh medium $\mathrm{I}$. The mucosa was discarded and the cell suspension finally incu- bated for 20 minutes at $37^{\circ} \mathrm{C}$. The cell suspension was then pipetted several times and filtered through 200 $\mu \mathrm{mol}$ sterile nylon mesh (Nytex, Tetko, Elmsford, NY). Four millilitres of the filtrate, containing cell clumps, was overlaid on $10 \mathrm{ml}$ of $0.5 \mathrm{~g} / \mathrm{dl}$ bovine serum albumin (BSA, Sigma) containing F-12 medium and centrifuged at $600 \mathrm{rpm}$ for five minutes. The pellet was washed three times with F-12 medium containing AA. The washed pellet was resuspended in medium II. Sterile technique was used throughout these procedures.

\section{COLLAGEN GEL PREPARATION}

Collagen was prepared from rat tails. One gram of the tendons of rat tails was dissolved in $300 \mathrm{ml}$ $1: 1000$ acetic acid solution. The solution was stored at $4^{\circ} \mathrm{C}$ for $48 \mathrm{~h}$ and then centrifuged at $2500 \mathrm{~g}$ at $4^{\circ} \mathrm{C}$ for 20 minutes. The supernate was stored at $4^{\circ} \mathrm{C}$ until dialysis. The solution was dialysed for $48 \mathrm{~h}$ using dialyser tubing (Fisher Scientific, Pittsburgh, PA). $0.5 \mathrm{ml}$ of dialysed solution was added to a 24 multiwell culture dish (Falcon, Oxnard, CA), and then gelled by exposure to ammonia vapour. Dishes were kept under ultraviolet light. Dishes were incubated with medium II two hours before use.

\section{CULTURE}

Medium II, containing cells, was inoculated onto the culture dish prepared as described above. About $3 \times 10^{5}$ cells in $0.5 \mathrm{ml}$ medium was inoculated into one well. The cultures were maintained in an incubator at $37^{\circ} \mathrm{C}$ in a humidified atmosphere of $5 \% \mathrm{CO}_{2}$ in air. The media was changed daily.

\section{MORPHOLOGICAL STUDIES}

Cultures were examined daily with a phase contrast microscope. Cells were stained with Giemsa solution on each day. A mitotic index was calculated. The trypan blue dye exclusion test for viability of isolated cells was carried out by the method of Phillips, ${ }^{4}$ as previously described.'

\section{HISTOCHEMICAL STUDIES}

To identify parietal cells succinic dehydrogenase activity was determined by the method of Nachlas $e t$ $a l .{ }^{10}$ The cultured cells were incubated in the medium containing $0.2 \mathrm{M}$ phosphate buffer $(\mathrm{pH} 7 \cdot 6), 0.2 \mathrm{M}$ succinic acid (disodium salt), and Nitro-BT $(1 \mathrm{mg} / \mathrm{ml}$, Sigma) for 60 minutes at $37^{\circ} \mathrm{C}$. Cells were counterstained by $1 \%$ saffranin. To distinguish mucous cells both periodic Acid-Schiff (PAS) and alcian blue (AB) staining were used. Cells were fixed with buffered formalin and stained with $1 \%$ alcian blue staining solution for 30 minutes. Cells were then also stained with PAS reagent. PAS staining alone was also performed. To stain chief cells, Bowie Stain was 


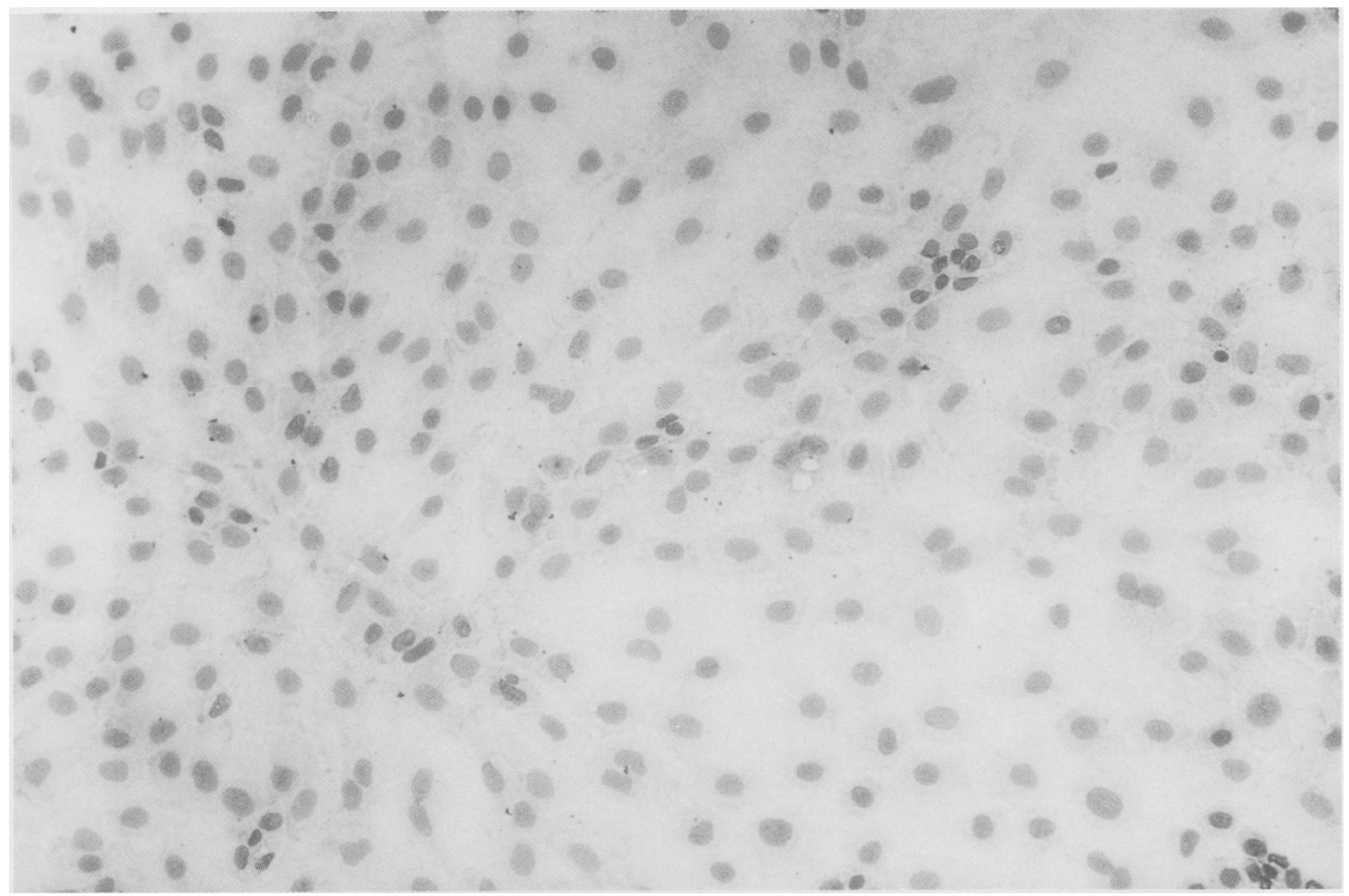

Fig. 1 Giemsa-stained adult rat gastric epithelial cells in tissue culture. Four day old culture. With this stain only cell nuclei stain prominently.

used." Neutral dye was prepared by mixing Orange $\mathrm{G}$ and crystal violet staining solution. Cells were stained with neutral dye solution for 10 minutes. These staining techniques were applied to gastric mucosa, isolated cell clumps, and cultured cells.

\section{EI. I:CTRON MICROSCOPY}

Monolayers were fixed with $2 \%$ glutaraldehyde for 20 minutes and postfixed with $1 \% \mathrm{OsO}_{4}$ for 20 minutes. The cells were dehydrated with graded alcohol and embedded in Epon 812 and polymerised at $60^{\circ} \mathrm{C}$ overnight. The sections were stained with uranyl acetate followed by lead citrate.

\section{IEI.I. GROWTH}

The number of cells in each well was counted each day using the nuclear counting method. '? Cultured cells were dislodged by incubation of the cells in $0.25 \%$ trypsin for 10 minutes. The cells were then incubated in ().1 $\mathrm{M}$ citric acid for one hour at $37^{\circ} \mathrm{C}$ and pipetted vigorously. The nuclei were collected by centrifugation at $2000 \mathrm{rpm}$ for 20 minutes and suspended in the $0.1 \%$ crystal violet solution. The nuclei were counted using a haemacytometer. The number of cells after isolation was also counted as described above.

\section{A UTORADIOGRAPHY}

Autoradiography was done using a modification of the procedure of Hamlin and Pardee. ${ }^{13}$ The cells were incubated with $1 \mu \mathrm{Ci} / \mathrm{ml}[3-\mathrm{H}] \mathrm{Tdr}$ for six hours each day. Cells were fixed with methanol and dried. NBT-2 emulsion was added to the cells. The cultures were stored in the dark at $4^{\circ} \mathrm{C}$ for one week. They were developed in Kodak D19 for six minutes and fixed in Kodak Rapid Fix for three minutes. The cells were poststained with haematoxylin. Labelling index was expressed as percentage of the labelled nuclei per 100 cells.

PROSTAGLANDIN PRODUCTION BY CULTURED

\section{GASTRIC CEILS}

Media contents of $\mathrm{PGE}_{2}$ and $6 \mathrm{KF}$ were measured by radioimmunoassay (RIA). Monolayers were washed three times with F-12 medium $\left(37^{\circ} \mathrm{C}\right)$ and incubated with medium for 30 minutes for further washing. 


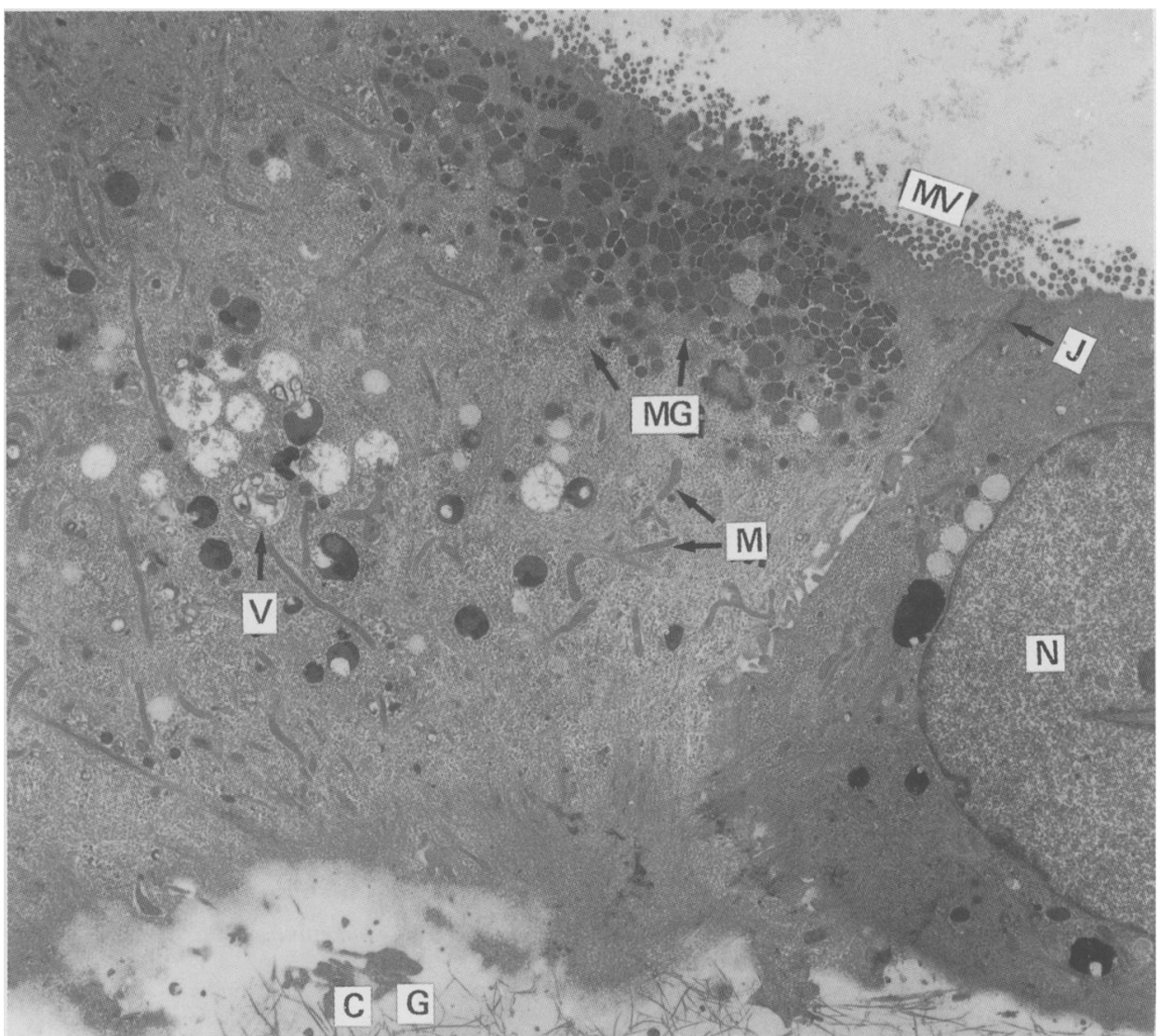

Fig. 2 Transmission electron micrograph of adult rat gastric cells in tissue culture, four day old culture showing cytoplasm of adjacent cells and tight junctions between cell membranes. $N$, nucleus; $M V$, microvilli; $m$, mitochondria; $M G$, mucous granules; $V$, autophagic vacuoles; $J$, junctional complex.

This medium was discarded and monolayers were incubated with medium containing test reagents or medium only for 60 minutes. The medium was collected and centrifuged for five minutes at $2000 \mathrm{rpm}$ and $4^{\circ} \mathrm{C}$. The supernatant was collected and stored at $-20^{\circ} \mathrm{C}$ until assayed. The pellet was combined with the corresponding monolayer and protein was determined with the dye binding assay according to Bradford. ${ }^{14} \mathrm{PGE}_{2}$ and $6 \mathrm{KF}$ content of media were assayed in duplicate with highly sensitive $\mathrm{PGE}_{2}$ and $6 \mathrm{KF} 125$-I RIA kits. Standards in the range of $0 \cdot 25$ to $50 \mathrm{pg} \mathrm{PGE}_{2}$ and 2 to $50 \mathrm{pg} 6 \mathrm{KF}$ were treated in the same way as the samples and the curve calculated on semi-logarithmic paper after counting in a Beckman 7000 gamma counter. The limits of detection were $0 \cdot 2$ pg $\mathrm{PGE}_{2}$ and $2.0 \mathrm{pg} 6 \mathrm{KF}$ per assay tube. For $\mathrm{PGE}_{2}$, cross-reactivity with $\mathrm{PGE}_{1}$ was $3.7 \%$ and with all other prostaglandins less than $0 \cdot 4 \%$. For $6 \mathrm{KF}$, crossreactivity with PGF-2a was $2.6 \%$ and for all other prostaglandins less than $2 \%$

\section{EXPERIMENTAI, DESIGN}

Effect of Na salicylate on cell viability

Cultured cells were incubated for one hour with: (a) medium only (control), (b) Na salicylate (). $1 \mathrm{mM}$, (c) Na salicylate $1 \mathrm{mM}$, (d) Na salicylate $10 \mathrm{mM}$, (c) Na salicylate $30 \mathrm{mM}$, (f) Na salicylate $50 \mathrm{mM}$. After incubation, cells were washed with medium and kept in $1 \mathrm{ml}$ of $\mathrm{F}-12$ medium. $0 \cdot 1 \mathrm{ml}$ trypan blue (0.4\%) was added to the medium. The number of stained or non-stained cells were counted and the percentage of viable cells was expressed as non-stained cells/ (stained + non-stained cells) $\times 100$. 


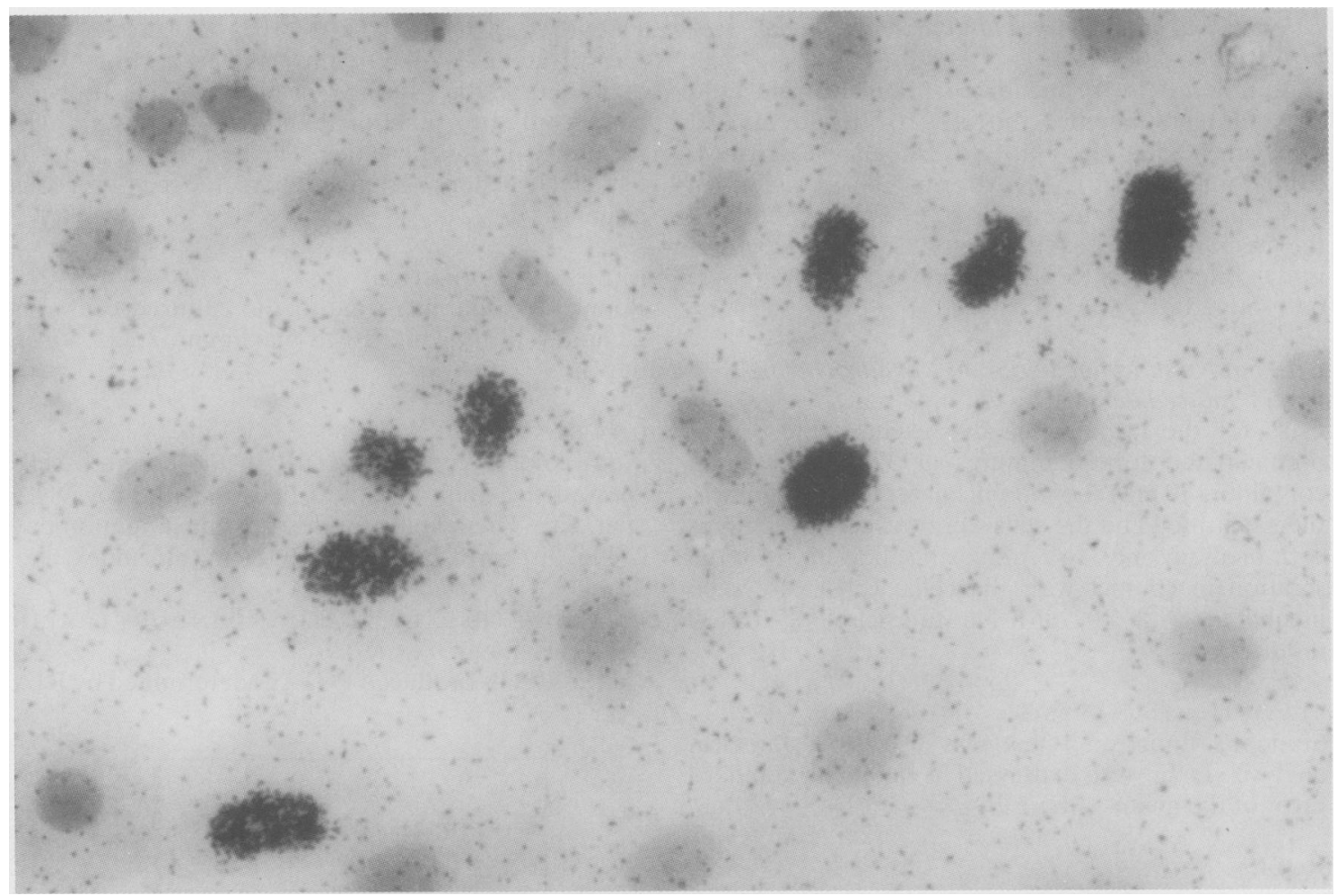

Fig. 3(a)

Fig. 3(b)

Fig. 3(a) Autoradiograph of [3H]thymidine incorporation in rat gastric epithelial cells in tissue culture (haematoxylin stain). Cells which contained more than 10 silver grains in the nucleus were considered as labelled cells. ${ }^{7}$

Fig. 3(b) Labelling indices determined by autoradiography of [3H]thymidine. Each point represents the mean (SE) of four cultures.

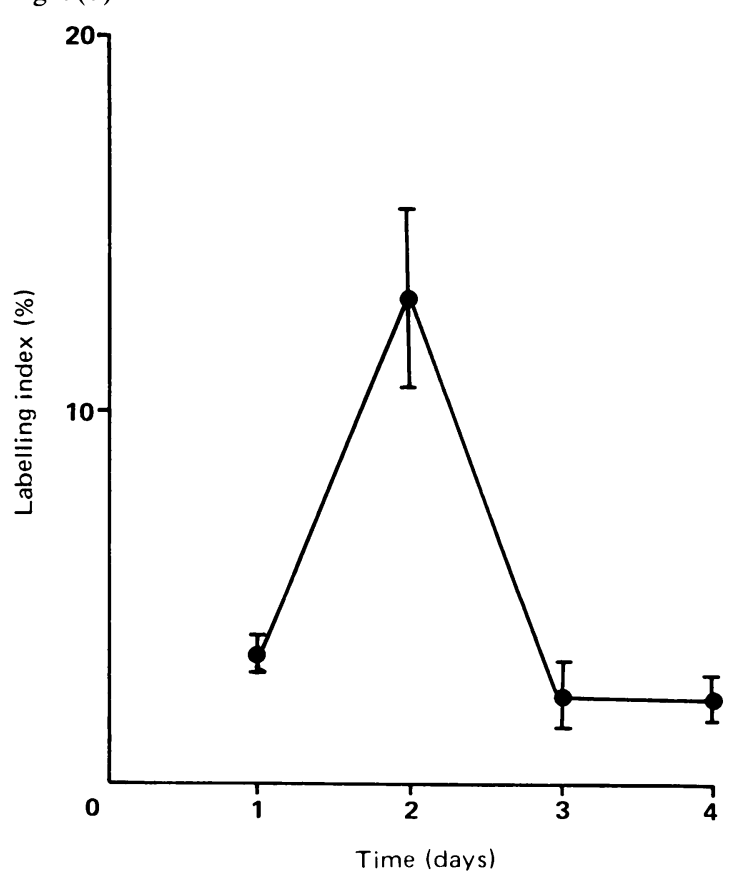


Effect of Na Salicylate and indomethacin on the production of $P G E_{2}$

Cultured cells were incubated for nil to one hour with: (a) medium only (control), (b) Na salicylate $0 \cdot 1$ $\mathrm{mM}$, (c) Na salicylate $1 \mathrm{mM}$, (d) Na salicylate $10 \mathrm{mM}$, (e) indomethacin $10^{4} \mathrm{M}$. After incubation, medium was collected and stored at $-20^{\circ} \mathrm{C}$. $\mathrm{PGE}_{2}$ content of the medium was assayed directly. Cells were trypsinised, collected by centrifugation and protein was determined. ${ }^{14}$

\section{Effect of Na salicylate ( $\mathrm{NaS}$ ) on Na taurocholate (NaT) induced damage}

Cells for the trypan blue dye exclusion test were preincubated for 30 minutes at $37^{\circ} \mathrm{C}$ in medium containing $10 \mathrm{mM}$ sodium salicylate; the medium was then aspirated and the cells were washed three times with medium only, to remove all salicylate from the solution in contact with the cells; cells were then incubated with $10 \mathrm{mM} \mathrm{Na}$ taurocholate for 30 minutes.

STATISTICALANALYSIS

Student's unpaired $t$ test was used for statistical analysis. Data were expressed as the mean standard error of the means (SE).

\section{Results}

LIGHT MICROSCOPY

Cell isolation: the cells from the final incubation were mainly composed of cell clumps and showed good viability ( $93 \pm 3 \%)$.

Cell culture: within one day after inoculation, the cell clumps attached to the surface of the collagen gel. The attachment of cells was markedly increased by use of collagen gel and by addition of fibronectin to the cell media. Cells began to grow and reached confluency on day 4 (Fig. 1). Over $99 \%$ of the cells at this stage had epithelial characteristics with only $0-1 \%$ fibroblasts. In most cultures by day 6 or day 7 fibroblasts were seen and their outgrowth started. Bacterial or fungal contamination was not observed up to two weeks.

HISTOCHEMICAL STUDIES

In the clumps after isolation of surface mucous cells, mucous neck cells, parietal cells and chief cells were observed. In four day old cultures, $94 \%$ of the cells contained PAS positive material in the cytoplasm; identifying them as mucous cells; $3 \%$ of the cells showed a strong reaction for succinic dehydrogenase activity consistent with parietal cells. Bowie staining for pepsinogen cells was negative; $3 \%$ of the cells were epithelial type cells which were unidentifiable histochemically.
TRANSMISSION ELECTRON MICROSCOPY Ultrastructurally, microvillus like projections were apparent on the surface of the cells. Cells were connected by junctional complexes with tight junctions and desmosomes. The majority of the cells had electron dense granules characteristic of mucous granules (Fig. 2).

\section{CELL PROLIFERATION}

Population doubling time of the cultured cells was 22 hours. Mitotic index was maximum, $2 \cdot 2 \pm 2 \%$, on day 2 .

DNA SYNTHESIS

Autoradiography of $[3 \mathrm{H}] \mathrm{TdR}$ in the cultured cells showed the ability of the cells to synthesise DNA (Fig. 3a). The labelling index was maximum on day 2 (Fig. 3b) corresponding with the mitotic index.

EFFECT OF Na SALICYLATE AND INDOMETHACIN ON PGE-2 PRODUCTION

Cultured cells produced $\mathrm{PGE}_{2}$ as determined by RIA

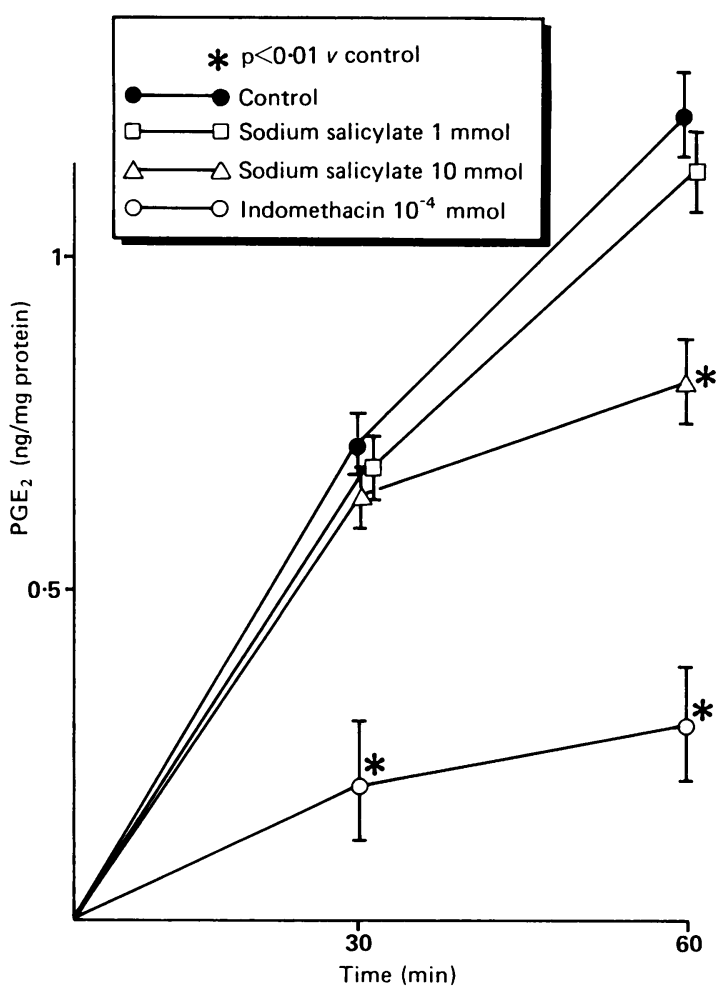

Fig. 4 The effect of sodium salicylate and indomethacin on the production of $P G E_{2}$. Each point represents mean (SE) of five to six cultures. Asterisks indicate statistically significant change from the control value $\left({ }^{*} p<0 \cdot 01\right)$. 


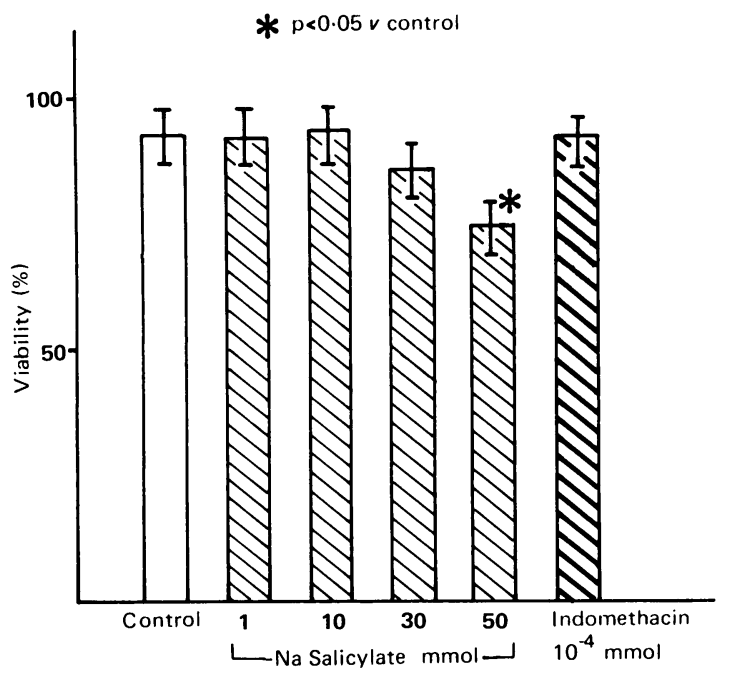

Fig. 5 Effect of sodium salicylate on cell viability. Each point represents mean (SE) of five to six cultures. Asterisk indicates statistically significant change from the control value $\left({ }^{*} p<0 \cdot 05\right)$.

$\left(1.21 \mathrm{ng} / \mathrm{mg}\right.$ protein/h). One millimole $\left(10^{-3} \mathrm{M}\right)$ and $0 \cdot 1 \mathrm{mM}\left(10^{-4} \mathrm{M}\right) \mathrm{Na}$ salicylate had no effect on $\mathrm{PGE}_{2}$ production (Fig. 4). After one hour's incubation 10 $\mathrm{mM}\left(10^{-2} \mathrm{M}\right) \mathrm{Na}$ salicylate weakly but significantly inhibited $\mathrm{PGE}_{2}$ production while $10^{-4} \mathrm{M}$ indomethacin strongly suppressed $\mathrm{PGE}_{2}$ production even at 30 minutes.

EFFECT OF Na SALICYLATE ON CELL VIABILITY After 60 minutes incubation, cultured cells showed good viability $(92 \pm 7 \%)$. Na salicylate up to a concentration of $30 \mathrm{mM}$ did not damage gastric mucosal cells. A concentration of $50 \mathrm{mM} \mathrm{Na}$ salicylate was necessary to damage the cultured cells significantly. Indomethacin $10^{-4} \mathrm{M}$ did not have any effect on cell viability (Fig. 5).

\section{EFFECT OF Na TAUROCHOLATE ON CELL \\ VIABILITY}

$\mathrm{Na}$ Taurocholate at $0 \mathrm{mM}$ and $2.5 \mathrm{mM}$ had no effect on cell viability; at $5 \mathrm{mM}$ and $10 \mathrm{mM}$ concentrations of $\mathrm{Na}$ taurocholate viability was reduced to $67 \pm 5 \%$ and $34 \pm 6 \%$ respectively (Fig. 6 ).

EFFECT OF Na SALICYLATE ON Na

TAUROCHOLATE INDUCED CELL DAMAGE

After preincubation with $10 \mathrm{mM} \mathrm{Na}$ salicylate followed by removal of the $\mathrm{Na} \mathrm{S}$, subsequent exposure to $\mathrm{Na} T 10 \mathrm{mM}$ resulted in $57 \pm 2 \%$ viability compared with $34 \pm 6 \%$ without $\mathrm{Na} \mathrm{S}(\mathrm{p}<0 \cdot 01)$ (Fig. $6)$.

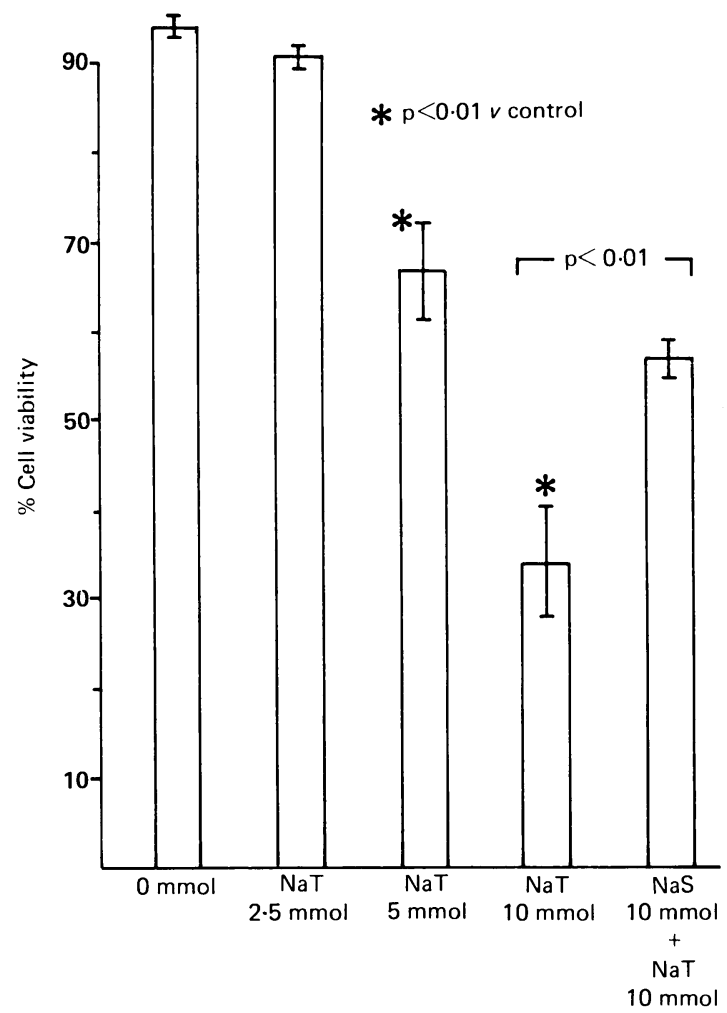

Fig. 6 Effect of sodium taurocholate ( $\mathrm{NaT})$ on cell viability. Protective effect of $10 \mathrm{mM}$ sodium salicylate (NaS).

\section{Discussion}

We have developed a monolayer culture of adult rat fundic epithelial cells. A major factor in the successful growth of adult cells in tissue culture as opposed to fetal cells was the use of collagen gel as a substrate to encourage the isolated adult cells to attach to the culture dishes. Monolayer culture systems of gastric mucosa have been reported using newborn rat gastric mucosa, ${ }^{7}$ fetal rabbit gastric mucosa, ${ }^{34}$ adult canine gastric mucosa, ${ }^{6}$ and adult human gastric mucosa. ${ }^{3}{ }^{15}$ In the present study, adult rat gastric mucosa was used which offers several advantages over fetal tissue culture cells: as adult rats are commonly used in most laboratories for in vivo studies, cultured cells from adult rats may more accurately reflect the physiological condition of adult gastric mucosa than fetal cells; adult rats are less expensive and less time consuming to obtain than are fetal rats from breeding colonies; experimental schedules consequently are much easier to arrange.

Fibroblast overgrowth has been a major problem of epithelial cell culture and various attempts to eliminate such contamination have been 
reported. ${ }^{16-19}$ In our previous report using newborn rats, ${ }^{7}$ about $5 \%$ fibroblasts were observed at the confluent stage (day 3 ). In the present study, less than $1 \%$ fibroblasts existed in culture up to day 5 and fibroblast overgrowth started much later. These findings are similar to those we reported with adult human gastric cell culture ${ }^{15}$ which was also relatively fibroblast free possibly because biopsy specimens contained very small numbers of fibroblasts thus fibroblast overgrowth could be avoided. Because the gastric mucosa of adult rats is thicker than that of baby rats, fewer fibroblasts may be obtained in the isolation process; alternatively, fibroblasts from adult rats may grow more slowly than those of baby rats.

The ability of the culture cells to proliferate and to synthesise DNA was shown by study of mitosis, incorporation of $[3 \mathrm{H}] \mathrm{TdR}$ into cellular nuclei, and cell growth. Most of the cells in this culture system were mucous cells. This indicates that of the mixed epithelial cells inoculated into the culture - that is, mucous cells, parietal cells, and chief cells, only the mucous cells were able to divide and replicate indicating that these cells were most likely mucous neck cells. Tissue cultures of mucous cells are particularly apt for studies of drug damage. In vivo in man, drug damage with common agents such as aspirin predominantly involves damage to the lining surface mucous cells. ${ }^{20}$ More severe necrotic damage as seen with experimental irritants such as absolute alcohol in animals is associated with concomitant ischaemic damage to the deeper layers of the mucosa; ${ }^{21}$ however, repair of this damage is dependent on the regenerative ability of the mucous (neck) cells. 2223

The cultured mucous cells produced $\mathrm{PGE}_{2}$. In a previous study, we have shown that such mucous cells produce more $\mathrm{PGE}_{2}$ than $\mathrm{PGI}_{2}$ in the order of $4: 1 .{ }^{24}$ Konturek et al $^{1}$ reported that $\mathrm{Na}$ salicylate increased $\mathrm{PGI}_{2}$-like activity by gastric mucosa in an in vivo rat study and attributed the cytoprotective effect of $\mathrm{Na}$ salicylate to this stimulation. In an in vivo study by Robert, however, Na salicylate induced cytoprotection which was not blocked by indomethacin, so that salicylate cytoprotection could not be attributed to prostaglandin production. ${ }^{2}$ Whittle et al in an ex vivo study reported that sodium salicylate inhibited prostaglandin production in subcutaneous inflammatory lesions but not in gastric mucosal tissue ${ }^{25}$ In an in vitro study of non-gastric cells, Na salicylate was found to be a weak cyclooxygenase inhibitor. ${ }^{26}$ The current studies are in agreement with these studies $^{225} 26$ and indicate that $\mathrm{Na}$ salicylate either has no effect on, or in pharmacological doses is a weak inhibitor of prostaglandin $E_{2}$ production by gastric mucous cells. These data also suggest that $\mathrm{Na}$ salicylate cytoprotection of gastric mucous cells is unlikely to be related to stimulation of $\mathrm{PGE}_{2}$ production by these cells.

Sodium salicylate was not toxic to cells except in the very high concentration of $50 \mathrm{mM}$. These results are similar to findings of lack of toxicity of sodium acetylsalicylate to tissue culture cells at neutral $\mathrm{pH}, 7 \cdot 4 .{ }^{27}$ Prostaglandin values were not measured after administration of damaging doses of sodium salicylate $(50 \mathrm{mM})$ or taurocholate. Cell death and lysis is itself associated with increased prostaglandin release, a non-specific effect.'

The protective effect of sodium salicylate on sodium taurocholate induced toxicity is consistent with its cytoprotective effects in vivo' and shows that such effects can also occur in vitro in the absence of systemic factors. These results are in agreement with our previous findings that the analgesic acetaminophen, which like salicylic acid is protective against drug damage to gastric mucosa in vivo,' is also cytoprotective in vitro. Furthermore, acetaminophen had no effect on $\mathrm{PGE}_{2}$ or $\mathrm{PGI}_{2}$ production in vitro and its cytoprotective effect in vitro was not blocked by indomethacin, although indomethacin significantly inhibited $\mathrm{PGE}_{2}$ and $\mathrm{PGI}_{2}$ production. ${ }^{28}{ }^{24}$

The conditions of these in vitro studies may be considered less physiological than in vivo studies in the sense that it is possible that both sides of the cells could be bathed in the media containing damaging agents. Nevertheless, in this and previous studies with varying agents cytoprotection could be demonstrated ${ }^{27-33}$ Indeed, cytoprotection of human isolated gastric glands by prostaglandins has recently been shown in spite of the cells being bathed on all sides by indomethacin or ethanol solutions ${ }^{34}$ Further, these authors found a correlation between the degree of protection in vitro of that found in their own in vivo studies. ${ }^{35}$ This indicates that cytoprotection is a function of the cell as a whole and is not dependent on which surface of the cell is exposed or on cell polarity.

Because these protected cells are in vitro, protection against taurocholate induced damage must include the direct effect of sodium salicylate on cell membranes or metabolism. Physiologically, taurocholic acid has a pKa of $<2$. Therefore at $\mathrm{pH} 7 \cdot 4$, it is entirely in the dissociated state with no lipid solubility or ability to penetrate the cell. At this $\mathrm{pH}$ its damaging action is limited to a detergent action on the external cell membrane. Salicylate affects the barrier function of the external cell membrane as indicated by preventing trypan blue from penetrating the cell; this suggests that the cell membrane is the site of the protective action of salicylate.

In summary, we have described a method for successful monolayer culture of adult rat gastric mucous epithelial cells. $\mathrm{PGE}_{2}$ production by these 
cells was inhibited by indomethacin but only weakly by sodium salicylate even at pharmacological concentrations. Sodium taurocholate damaged gastric cells most likely by a detergent type action on the external cell membrane. Sodium salicylate at neutral $\mathrm{pH}$ was not damaging to cells except at very high concentrations. Sodium salicylate was protective against sodium taurocholate induced damage to gastric mucosal cells in vitro independent of systemic factors. This direct protective effect appears to be on the external cell membrane and is unlikely to be mediated by increased cellular metabolism of prostaglandins.

This work was supported in part by the Medical Research Service of the Veterans Administration. This work was done while Dr Ota was a visiting scientist from the 2nd Department of Medicine, University of Tokyo, Japan.

\section{References}

1 Konturek SJ, Brzozowski T, Piastucki I, Radechi T. Prevention of ethanol and aspirin-induced gastric mucosal lesions by paracetamol and salicylate in rats: role of endogenous prostaglandins. Gut 1982; 23: 53640.

2 Robert A. Gastric cytoprotection by sodium salicylate. Prostaglandins 21 [suppl]: 1981: 139-41.

3 Miller LR, Jacobson ED, Johnson LR. Effect of pentagastrin on gastric mucusol cells grown in tissue culture. Gastroenterology 1973; 64: 254-67.

4 Matuoka K, Tanaka M, Mitsui Y, Murota S. Cultured rabbit gastric epithelial cells producing prostaglandin $\mathrm{I}_{2}$. Gastroenterology 1983; 84: 498-505.

5 Logsdon CD, Bisbee CA, Rutten MJ, Machen TE. Fetal rabbit gastric epithelial cells cultured on floating collagen gels. In Vitro 1982; 18: 233-42.

6 Ayalon A, Sanders MJ, Thomas LP, Amirian A, Soll AHH. Electrical effects of histamine on monolayers found in culture from enriched canine gastric chief cells. Proc Natl Acad Sci USA 1982; 79: 7009-13.

7 Terano A, Ivey KJ, Stachura J, et al. Cell culture of rat gastric fundic mucosa. Gastroenterology 1982; 83: 128091.

8 Coon HG, Weiss MC. A quantitative comparison of formation of spontaneous and virus-produced viable hybrids. Proc Natl Acad Sci USA 1969; 62: 852-69.

9 Phillips HJ. Dye exclusion tests for cell viability. In: Krause PF, Patterson MK, eds. Tissue culture methods and applications. New York: Academic Press, 1973: 406-8.

10 Nachlas MM, Tsou KC, Souza ED, Cheng CS, Seligman AM. Cytochemical demonstration of succinic dehydrogenase by the use of a new p-Nitrophenyl substituted ditetrazole. J Histochem Cytochem 1957; 15: 420-36.

11 Bowie DJ. A method for staining the pepsinogen granules in gastric glands. Anat Rec 1935; 64: 357-62.
12 Paul J. Cell and tissue culture. Edinburgh: Churchill Livingstone, 1975:363-4.

13 Hamlin J, Pardee AB. S phase synchrony in monolayer CHO cultures. Exp Cell Res 1976; 100: 265-75.

14 Bradford $M$. A rapid and sensitive method for the quantitation of microgram quantities of protein utilizing the principle of protein-dye binding. Anal Biochem 1976; 72: 248-54.

15 Terano A, Mach T, Stachura J, Sekhon S, Tarnawski A, Ivey KJ. A monolayer culture of human gastric epithelial cells. Dig Dis Sci 1983; 28: 595-603.

16 Gilbert SF, Migeon BR. D-Valine as a selective agent for normal human and rodent epithelial cells in culture. Cell 1975; 5: 11-17.

17 Owens RB. Selective cultivation of mammalian epithelial cells. In: Prescott DM, ed. Methods of Cell Biology. New York: Academic Press, 1976: 341-55.

18 Quaroni A, Wants J, Trestad RL, Isselbacher KJ. Epithelioid cell culture from rat small intestine. J Cell Biol 1979; 80: 248-65.

19 Weber MM. Normal and benign human prostatic epithelium in culture. I. Isolation. In vitro. Cell Dev Biol 1979; 15: 967-82.

20 Baskin W, Ivey KJ, Krause W, Jeffrey GE. Aspirininduced ultrastructural changes in human gastric mucosa. Correlation with potential difference. Ann Intern Med 1976; 85: 299-303.

21 Hollander D, Tarnawski A, Ivey KJ, DeZeery A. Arachidonic acid protection of rat gastric mucosa against ethanol injury. J Lab Clin Med 1982; 100: 296308.

22 Tarnawski A, Hollander D, Stachura J, Krause WJ, Gergely $\mathrm{H}$. Prostaglandin protection of the gastric mucosa against alcohol injury - a dynamic time-related process. Gastroenterology 1984; 88: 334-52.

23 Tarnawski A, Stachura J, Ivey KJ. Are prostaglandins 'cytoprotective'? Time sequence of morphologic and functional protection of gastric mucosa against ethanol. Gastroenterology 1982; 82: 1193.

24 Ota S, Razandi M, Dadhaniya K, Terano A, Ivey KJ. Phospholipase activity and prostaglandin synthesis in gastric epithelial cell culture. Gastroenterology 1984; 86: 1203.

25 Whittle BJR, Higgs GA, Eakins KE, Moncada S, Vane $J R$. Selective inhibition of prostaglandin production in inflammatory exudates and gastric mucosa. Nature 1980; 284: 271-3.

26 Vane JR. Inhibition of prostaglandin synthesis as a mechanism of action for aspirin-like drugs. Nature 1971; 231: 232-5.

27 Terano A, Mach T, Stachura J, Tarnawski A, Ivey KJ. Effect of 16,16 dimethyl prostaglandin $E_{2}$ on aspirininduced damage in rat gastric cultured cells. Gut 1984: 25: 19-24.

28 Ota S, Razandi M, Sekhon S, Terano A, Ivey KJ. Acetaminophen protects gastric mucosal cells against sodium taurocholate-induced damage to monolayer cultures in rats. Gastroenterology 1984; 86: 1203.

29 Ota S, Razandi M, Sekhon S, Terano A, Hiraishi H, Ivey KJ. Cytoprotective effect of acetaminophen against taurocholate-induced damage to rat gastric monolayer cultures. Dig Dis Sci 1988; 33(8): 938-44. 
30 Terano A, Ota S, Mach T. Hiraishi H, Stachura J, Tarnawski A. Ivey KJ. Prostaglandin protects against taurocholate-induced damage to rat gastric mucosal cell culture. Gastroenterology 1987; 92: 669-77.

31 Hiraishi H, Terano A, Ota S, Ivey KJ, Sugimoto T. Oxygen reactive metabolite-induced cytotoxicity to cultured rat gastric mucosal cells. Am J Physiol 1987; 253: G40-8.

32 Hiraishi $H$, Terano A, Ota S, Ivey KJ, Sugimoto T. Effect of cimetidine on indomethacin-induced damage in cultured rat gastric mucosal cells; comparison with prostaglandin. J Lab Clin Med 1986; 6: 608-15.
33 Romano M, Razandi M, Sekhon S, Krause WJ, Ivey KJ. A human cell line for study of damage to gastric epithelial cells in-vitro. J Lab Clin Med 1988; 111: 430-8.

34 Tarnawski A, Brzozowski T. Sarfeh J, et al. Prostaglandin protection of human isolated gastric glands against indomethacin and ethanol injury. J Clin Invest 1988; 81: 1081-3.

35 Tarnawski A, Hollander D, Stachura J, Krause WJ, Gergely $H$. Prostaglandin protection of the gastric mucosa against alcohol injury, a dynamic time related process. The role of the mucosal proliferative zone. Gastroenterology 1985; 89: 366-74. 